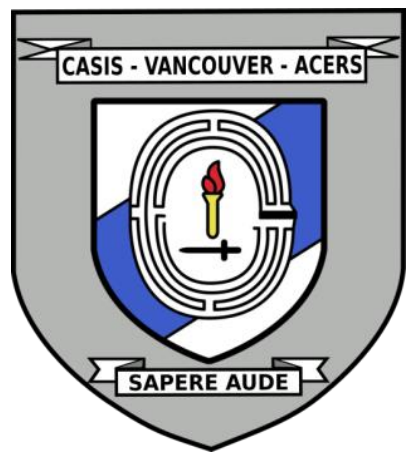

\title{
EFFECTIVE LEADERSHIP IN TIMES OF UNCERTAINTY
}

Date: November 26, 2021

Disclaimer: This briefing note contains the encapsulation of views presented by the speaker and does not exclusively represent the views of the Canadian Association for Security and Intelligence Studies.

\section{KEY EVENTS}

On November 26, 2021, Lt. Col. Vincent Virk, Commanding Officer of the British Columbia Regiment (Duke of Connaught's Own), presented Effective Leadership in Times of Uncertainty at the 2021 CASIS West Coast Security Conference. The presentation was followed by a question and answer period with questions from the audience and CASIS Vancouver executives. The key points discussed were the three spheres of leadership (institutional, people, self), genuine leadership requiring development, and the importance of individuals and the team.

\section{NATURE OF DISCUSSION}

\section{Presentation}

In the Canadian Armed Forces (CAF), leadership is broken into three spheres: institutional leadership, leading people, and leadership of self. Institutional leadership is about establishing the strategy of the force writ large. Leading people is about instilling institutional values in people and teams. The result of leadership of self is the ability to apply all the necessary traits of leading others in the long run. All these spheres are necessary to ensure that teams work effectively.

\section{Question Period}

Leadership in the armed forces and its relation to leadership in other contexts was discussed, as well as the topic of leadership as a skill. Additionally, the issue of right-wing extremism (RWE) infiltration in the CAF was addressed. 


\section{BACKGROUND}

\section{Presentation}

Leadership is not something that can be defined but rather a concept that arises due to the demands of an environment where people are engaged in a joint activity. In the Canadian Armed Forces (CAF), leadership is broken into three spheres: institutional leadership, leading people, and leadership of self.

Institutional leadership is about establishing the strategy of the force writ large and defined as the entire development and maintenance of the framework in which everyone operates. This includes a system of checks and balances to ensure the end state is conducive to the institutional goals and vision of the CAF. For the CAF, what defines the profession is the military ethos, which comprises values, beliefs, and expectations that reflect core Canadian values. This ethos exists to guide and shape the development of military leaders; establish a basis for personnel policy and doctrine; enable professional self-regulation; establish trust between the CAF and Canadian society; and assist in identifying and resolving ethical challenges. As a values-based organization, CAF members must live the values they espouse, not just strive for them.

Effective leadership is found in having effective teams. These teams are required to understand and apply institutional values in establishing the outcomes they should strive to achieve and the professional standards they should use to guide and regulate their conduct. Therefore, understanding and teaching the institutional components to the people in these teams is a constant and necessary component of leadership. Leadership in itself is not something distinct and compartmentalized, but rather envelops all components of human interactions. In general, the necessity for leaders to direct and motivate subordinates to any significant degree will largely depend on their state of development. The ultimate objective of military training and socialization is to transform green recruits into fully capable and confident professionals who can operate as a cohesive team. These principles of leadership have evolved over time in the CAF into responsibilities that all leaders must uphold.

Leadership of self is the most vital of the three spheres. If you're not developed enough as an individual, genuine leadership will not be possible in the long-term. Mental fitness is equally as important as physical fitness. Both body and mind need to be exercised to develop. Grit is important to maintain this constant growth; it is the passion and perseverance to pursue a long-term goal by organizing and giving meaning to almost everything that you do, even when 
progress towards the goal is slow. The end result of leadership of self is the ability to apply all the necessary traits of leading others for an extended duration of time and being able to consistently draw upon those traits and lead to self-growth versus wearing out.

The pandemic has brought about the need for leaders to communicate, articulate, and clearly define what your wants and needs are to a team which you may not even see for days, weeks, or months on end. This is vital in ensuring that a team moves forward together effectively. Future enhancements and changes for better leadership should be added on the institutional, team, or individual level in an ever-evolving landscape. It requires constant effort and understanding of the environment around you. For the military, applying the ethos through all three levels ensures continued effort across complex organizations, such as the CAF, top to bottom. However, at each level, applications of creative approaches are necessary to stay relevant within the times.

\section{Question Period}

Some people feel leadership in the military is different than other environments, but it is the same. Leadership styles are distinct without a one fits all technique. There can be leaders that could either be a horrible human being or a wonderful human being, both with effective leadership skills. One thing one should not do is make it about oneself. If one is leading individuals, the team takes precedence.

Leadership is not a role and should not be confused with command, managing, or a specific position. There are times where a team has successes and strengths, and a certain individual can be a leader for that only a moment. There are opportunities for everyone to lead, but not everyone is a leader.

RWE in the CAF is not currently a rampant concern, but all leaders in the organization are being educated and made aware of it. However, there are concerns about the CAF being infiltrated or targeted by extremists. Recruits get targeted not only by RWE, but also by organized crime. There are lots of layers to the problem, and the CAF is focused on creating resiliency among its soldiers. 


\section{KEY POINTS OF DISCUSSION}

\section{Presentation}

- There are three important spheres of leadership: institutional leadership, leading people, and leadership of self. Leadership of self is the most vital of the three spheres.

- Institutional leadership is defined as the entire development and maintenance of the framework under which everyone operates.

- Understanding and teaching the institutional components to the people within teams is a constant and necessary component of leadership.

- If you're not developed enough as an individual, genuine leadership will not be possible in the long-term.

- Future enhancements and changes for better leadership should be added on the institutional, team, or individual level in an ever-evolving landscape.

\section{Question Period}

- Leadership in the military is the same as in other environments.

- There are opportunities for everyone to lead, but not everyone is a leader.

- There is not a rampant concern about right wing extremism in the CAF, but all leaders in the organization are being educated and made aware of it.

\section{c)}

EY NC ND This work is licensed under a Creative Commons Attribution-NonCommercial-NoDerivatives 4.0 International License.

(C) (VINCENT VIRK, 2022)

Published by the Journal of Intelligence, Conflict, and Warfare and Simon Fraser University

Available from: https://jicw.org/ 